\title{
The Effects of Public Housing on Internal Mobility in Hong Kong
}

\author{
Hon-Kwong Lui* \\ Lingnan University \\ and \\ Wing Suen \\ The University of Hong Kong
}

(Revised July 2010)

\begin{abstract}
The rationing of public housing reduces the efficiency of the match between public housing units and their occupants, as competing users cannot effectively convey their preferences through a price mechanism. This study investigates the costs of public housing from the perspective of the misallocation of housing units to households and examines how this misallocation affects their lives. We show that public housing occupants are less mobile than private housing occupants, but conditional on moving, they are more likely to relocate farther away from their original place of residence. They are also less likely to work in the same place as they live.
\end{abstract}

JEL Code: R21, I38, H53

\footnotetext{
* Correspondence to: Hon-Kwong Lui, Department of Marketing \& International Business, Lingnan University, Tuen Mun, Hong Kong, CHINA; Voice: (852) 2616-8233 Fax: (852) 2616-5548 Email: hklui@ln.edu.hk

We thank the Editor and an anonymous referee for useful comments and suggestions that significantly improved the quality of the paper.
} 


\section{Introduction}

Public housing represents a sizable subsidy to housing cost and it has to be strictly rationed among competing users. When rationing occurs, resources may not be allocated to their most valuable uses because people cannot effectively convey the intensity of their preferences. Consider, for example, two otherwise identical housing flats available for allocation between two prospective tenants. Flat $\mathrm{A}$ is located in a more desirable neighborhood than Flat $\mathrm{B}$, so both prospective tenants are willing to pay a premium rent for Flat A. Suppose the first person also happens to work in the same neighborhood as the location of Flat A, and he is prepared to pay a higher premium for Flat $\mathrm{A}$ than is the second prospective tenant. In an open market, Flat A will be allocated to the person who values it more, namely the first prospective tenant. When rents are fixed at subsidized levels and flats are allocated by non-market means, however, both prospective tenants will reveal (truthfully) that they prefer Flat A to Flat B. There is no means to administratively determine which of the two is the higher-value user for the more desirable flat. In practice, subsidized housing is often allocated on the basis of stated preferences supplemented by some lottery or queuing mechanism. The purpose of this paper is to study some of the inefficiencies induced by the use of non-price methods of allocation in the provision of public housing in Hong Kong.

The misallocation of resources under non-price methods of allocation draws from a large and well-established literature in economics (e.g., Cheung, 1974; Weitzman, 1977; Suen, 1989; Glaeser and Luttmer, 2003). When a good is allocated at below-market price, there is insufficient incentive for sellers to produce the good. The resulting under-supply of the subsidized good leads to the famous "deadweight loss" illustrated in economics textbooks. Less well recognized is the fact that competition for the price subsidy generally leads to the dissipation of value. Barzel (1974) shows how equilibrium can be achieved through socially wasteful rationing by waiting. In the context of public housing, prospective tenants may distort their labour supply decisions lest their income exceeds the eligibility threshold, while incumbent tenants may choose to inefficiently stay in their flats upon changing circumstances lest they lose the valuable subsidy. Yet a third source of inefficiency is that, when individuals cannot express their intensity of preferences through their willingness to pay, non-price 
methods of allocation generally fail to allocate scarce resources to the highest-value users. If a flat worth a rental of $\mathrm{HK} \$ 10,000$ a month is being rented at $\mathrm{HK} \$ 2,000$, any prospective tenant whose value for the flat exceeds HK $\$ 2,000$ will be interested in bidding for it. Depending on the allocation method being adopted, the flat may well end up in the hands of someone whose value for it is well below HK\$10,000. Deacon and Sonstelie (1989; 1991) and Suen (1989) analyze the welfare costs arising from such misallocation of resources when rationing is by waiting. In a more recent study, Glaeser and Luttmer (2003) study the misallocation of housing in New York City under rent control. They find that the matching of the characteristics of tenants to the characteristics of their housing units is distorted for flats under rent control. Since rent control also represents a housing subsidy to existing tenants, Glaeser and Luttmer's (2003) insight is equally applicable to the analysis of government-subsidized housing.

In Hong Kong, public housing affects a large fraction of the population. In 2009, 29 percent of the households were tenants in government-provided housing, and another 18 percent owned subsidized housing through the Home Ownership Scheme and related programs (Hong Kong Housing Authority, 2010a). Critics of public housing policy often focus on the fiscal burden imposed by such massive subsidies. Less well researched are costs from the allocative inefficiencies induced by rationing subsidized housing. Although these costs may be less tangible than the direct fiscal costs, they can have a more immediate impact on people's everyday lives. In this paper, we focus on distortions on location choices induced by public housing.

Public housing benefits tend to tie down tenants to their current location; residents in public housing are expected to be less likely to move to more convenient locations or more suitable housing units even after their life circumstances have changed. This hypothesis is related to the literature on the "job lock" effect on job mobility (e.g., Madrian, 1994; Gilleskie and Lutz, 2002; Adams, 2004; Bansak and Raphael, 2008). That literature examines the effect of employer-provided health insurance on job mobility, the hypothesis being that workers are reluctant to switch their jobs lest they lose their insurance coverage. In a similar vein, we 
examine the hypothesis that public housing benefits deter internal mobility because occupants do not want to lose their substantial housing subsidy. ${ }^{1}$

In the urban studies literature, there is a substantial body of work documenting the empirical patterns of internal migration (e.g., Greenwood, 1985; Elliott, 1997; Painter, 1997). Boyle and Shen (1997) study the effect of public (council) housing on internal migration in Britain and find that public housing occupants are less likely to migrate long distances outside the area of the local council. In a recent paper, Kim et al. (2005) demonstrate that transport related attributes have significant impacts on residential location choice and individuals prefer locations with a combination of shorter commuting time, lower transport costs, lower density and higher quality of school. In the United States, public housing complexes are often clustered in central-city locations with high concentration of poverty (Quigley, 2000). Many believe that living in such neighborhoods limits one's economic opportunity (Wilson, 1996). To reduce economic segregation induced by project-based public housing provision, the U.S. Department of Housing and Urban Development has experimented with tenant-based rental subsidies to encourage them to move from high-poverty to low-poverty areas (e.g., the Moving to Opportunity Program). Johnson et al. (2002) report that families who take advantage of these programs to move to low-poverty areas experience reductions in welfare dependence and improvements in health status. There is also evidence that such moves may improve children's schooling outcomes and reduce their problem behaviours (see also Feins and Shroder, 2005; Ludwig et al., 2005; Rosenbaum and Harris, 2001).

In addition to the lack of internal mobility, another manifestation of the distortions in location choices induced by public housing is the mismatch between place of residence and place of work. A competitive rental market solves the efficient assignment problem as housing units go to their highest-value users (Koopmans and Beckmann, 1957). The price system fails to perform this function when rents for public housing units are fixed and the allocation of units in excess demand is determined by non-price means. Moreover, even when there is no initial mismatch between place of residence and place of work, people's circumstances change. When circumstances (e.g., change to a new job) prescribe moving to another area, the lack of

\footnotetext{
${ }^{1}$ If they want to move to another subsidized unit, the administrative hurdles and waiting time are substantial because of the persistent shortage induced by below-market prices.
} 
mobility on the part of public housing tenants may hinder the optimal reallocation of resources. The determination of residential and work location is a well researched topic in urban economics (e.g., Vickerman, 1984; Siegel, 1975; Simpson, 1987; Kan, 2002; Kan 2003). Also of some relevance to our present work is the literature on the "spatial mismatch hypothesis" of Kain (1968). Kain's work was originally related to how residential segregation adversely affected the employment opportunities of blacks in the United States (see also Holtzer, 1991). Although residential segregation by race is not a major problem for Hong Kong, the fact that public housing estates are often located far from centers of economic activities may have implications for the mismatch between place of residence and place of work.

Moreover, housing tenure also plays an important role in determining residential mobility and employment (e.g., Ioannides and Kan, 1996; Kan, 2000; Dohmen, 2005). Battu et al. (2008) study the effects of housing tenure on individuals' job and unemployment durations in the United Kingdom. They argue that home ownership and public rental housing impose more constraint on employed and unemployed, respectively. Munch et al. (2008) argue that home ownership has a negative effect on the unemployment risk and a positive impact on wages. Huang and Deng (2006) show that housing tenure has consistent but different effects on mobility over time in China. Helderman et al. (2004) argue that there is a decrease in the effect of homeownership on residential mobility given a rapid rise in homeownership in the Netherlands. Munch et al. (2006) suggest that homeownership hampers the propensity to move for job reasons but improves the chances of finding local jobs. As the availability of subsidized sale flats in Hong Kong is more restrictive than that of private sector, public home owners will face a higher distortion in location choice than private counterparts. This may also have implications for the mismatch between place of residence and place of work among home owners.

In this paper, we use the census sample of Hong Kong to examine the allocative inefficiencies induced by rationing subsidized housing and how this misallocation affects these tenants' behaviour concerning internal mobility and travel-to-work. The empirical results suggest that public housing occupants are more immobile and are less likely to work in the same district or region as their place of residence than their private housing counterparts. 
Moreover, conditional on moving, public housing occupants are more likely than their private housing counterparts to have to move outside their original district or region of residence. They are also less likely to work in the same place as they live. Our conclusions are based on probit regressions of mobility and travel behaviours on public occupancy status. We try to control for other determinants of such behaviours by including an extensive set of control variables in our regressions. Many of our regression models are estimated using hundreds of variables. However, we cannot exclude the possibility that there are some remaining unobserved differences across occupancy groups that affect mobility. The empirical results presented in this paper should be interpreted with this caveat in mind.

\section{A Brief Review of the Public Housing Allocation System}

In Hong Kong there are approximately two million people (about 30\% of Hong Kong's population) living in 700,000 public rental flats provided by the Housing Authority (Hong Kong Housing Authority, 2010b). Public housing applicants or their family members must not directly or indirectly own or co-own any domestic property. Moreover, applicants are subject to income and total net asset value limits as laid down by the Housing Authority.

The Housing Authority maintains a waiting list of public rental housing applicants. From this list, eligible applicants are offered accommodation in public rental housing estates. When an applicant's turn comes, the applicant will be given a maximum of three offers (one option in each offer) of public rental housing in the district of his/her choice. The application will be cancelled if the applicant fails to provide acceptable reason for refusing all the three housing offers (Hong Kong Housing Authority, 2010b). Public rental housing estates are grouped into four broad districts, namely Urban, Extended Urban, the New Territories, and the Islands. Since there are insufficient public rental housing units in the Urban district that can be allocated to all applicants, applicants can only choose one district from among the three nonurban areas for their future housing allocation. As of July 2010, there were more than 130,000 applicants on the waiting list (Hong Kong Housing Authority, 2010b). The Housing Authority sets a target of maintaining the average waiting time at three years. 
In the process of public housing allocation, applications are processed strictly in accordance with the application sequence numbers and the applicants' choices of district. However, those who fulfill the eligibility criteria of the Express Flat Allocation Scheme may have an earlier chance to be allocated public rental housing units. There are also separate criteria and allocation schemes for people affected by squatter clearance and public housing redevelopment.

According to existing public housing policies, public housing tenants may apply for flat transfer under various situations such as increased family size, special medical or social grounds, or major improvement or redevelopment programs implemented by the Housing Authority (Hong Kong Housing Authority, 2010c). ${ }^{2}$ Whenever possible, eligible tenants will be transferred to suitable flats within the same estate. Tenants may also apply for special transfer to another estate. Due to persistent shortage of public rental housing units, even if a tenant is eligible for flat transfer, the waiting time can be quite long and there is no guarantee that the new flat will match the tenant's preferences.

Besides applying for a public rental housing unit, eligible households can also apply to buy subsidized flats through the Home Ownership Scheme (HOS). ${ }^{3}$ In setting the price of HOS flats, the Housing Authority follows three guiding principles: (i) the mortgage-to-income ratio should not be more than 40 percent; (ii) 50 percent of the flats should be affordable to the target group; and (iii) flats should be offered at a 30 percent discount of market value.

Starting from the third year of occupancy, HOS flat owners may sell their flats in the open market after paying a premium to the Housing Authority. The premium is basically equal to the prevailing market value multiplied by the discount enjoyed by the owner at the time of purchase. For example, if the prevailing market value of a HOS flat is HK\$2,000,000 and the flat was offered at a discount of 30 percent at the time of purchase, then the premium is equal to HK\$600,000. Owners of HOS flats can also sell their flats to existing public rental housing tenants. In this case, the original HOS owner will not be required to pay the premium to the

\footnotetext{
${ }^{2}$ In the past, public housing tenants could participate in the Tenant Mutual Exchange Scheme, which would arrange a maximum of four matches in order to enable them to exchange their flats. However, the scheme ceased operation in early 2006. It should be noted that unauthorized exchanges among tenants are regarded as breach of tenancy agreements, resulting in termination of their tenancies.

${ }^{3}$ Due to the collapse of the property market, the government suspended the production and sale of HOS flats indefinitely from 2003 onwards.
} 
Housing Authority before selling the flat, but the purchaser will inherit the liability to pay the premium should he or she seek to sell the flat in the open market later on. With these restrictions in place, the secondary market for HOS flats is quite inactive.

\section{Empirical Framework}

The data set we use in this study is a random sub-sample of the Hong Kong Population Census. Relying on information from the population census file, we compare the pattern of internal mobility between public housing and private housing occupants. A study of public housing in Hong Kong (Wong and Liu, 1988) adopts a similar approach, but the focus of that study is on the distortion in the level of housing consumption. Wong (1998) elaborates this and other distortions induced by public housing, and makes a case for privatization. By introducing another dimension to the misallocation problem (namely, mobility and location choice), our study adds to the debate concerning various policy alternatives such as privatization or privatemarket rent subsidy. Although housing tenure plays an important role in mobility, the crosssectional data set used in this study does not contains adequate information for more in-depth analysis. Hence, this paper should be read with this limitation in mind.

Because of a persistent shortage of subsidized housing, it is much more difficult for a public housing tenant to obtain relocation to another public housing unit than for a private housing occupant to move to another flat. Moreover, it is often an unrealistic option for public housing tenants to move to a private flat because doing so entails losing a substantial government subsidy. This is similar to the idea of the "job lock" effect in labour economics (Madrian, 1994; Gruber and Madrian, 1994). In the "job lock" effect, one may argue that the value of health insurance provided by the employer is not a pure subsidy because of possible compensating wage differences. In the case of government housing, the low rental is indeed a subsidy. We therefore expect the "housing lock" effect on internal migration to be even stronger than the "job lock" effect on job mobility. We hypothesize that, other things equal, public housing occupants are more immobile than private housing occupants (Hypothesis I).

We argue that public housing occupants are less mobile than private housing occupants because the range of options available to them is more limited. By the same logic, if we 
compare people who actually made a move, we expect to find that a tenant in public housing is less likely to move to a unit that matches his preferences. Therefore, conditional on moving, we expect that public housing tenants are more likely than their private housing counterparts to have to move farther away from their original district or region of residence (Hypothesis II).

Another distortion created by public housing is that public housing benefits tend to tie down tenants to their current location. When circumstances change, such as change to a new job or having a baby, one may consider moving to live in another location. Siegel (1975) examines the relationship between the home and job location of the household within a metropolitan area (see also Simpson, 1987). However, tenants in public housing are less likely to move to more convenient locations and their location choices may not accurately reflect their true location preferences. In an earlier study in the United Kingdom, Hughes and McCormick (1987) show that public housing inhibits local movement for job-related reasons. We therefore hypothesize that public housing tenants are less likely to work in the same district or region as their place of residence (Hypothesis III).

Similarly, the market size for subsidized sale flat is much smaller than that of private sector and these subsidized flats are often located far from centers of economic activities. When a household determines to buy a subsidized flat, the location choice may not accurately reflect their true location preference. Therefore, conditional on moving, we expect that owners of public housing are more likely than their private home owners to have to move farther away from their original district or region of residence (Hypothesis IV). When compare with the private sector, public home owners are less likely to move to more convenient locations. We therefore hypothesize that public home owners are less likely to work in the same district or region as their place of residence (Hypothesis V).

These hypotheses are tested using probit regressions on census data in 2001. The census data set contains information about whether a household has moved in the previous five years, and information about the past and present districts of residence. Additional variables such as income and education can be used to control for other differences between public and private housing occupants. However, there may be unobservable differences between public and private housing occupants that affect our outcome variables. Because we do not have 
convincing instrumental variables, it is difficult to tease out the direct effect of public housing from the indirect effects induced by the correlation between public housing occupancy and unobservable variables. We will attempt to partially address this issue by introducing an extensive set of control variables. But to the extent that there are important unobserved differences across occupancy groups that affect the outcome variables, the estimates from our probit regressions cannot be given a causal interpretation.

Suppose a dummy variable $M$ is equal to 0 if a tenant has not moved in the previous five years, and $M=1$ if the tenant has moved. The probability that $M=1$ can be represented by a probit model with $\mathrm{M}$ as dependent variable. The independent variable of interest is whether the tenant resides in public or private housing. We also include an extensive set of control variables such as age, gender, education, income, spouse, household size, marital status, employment status, dummy variables for young children, and industry and occupational dummy variables. Based on Hypothesis I, we predict the coefficient estimate for the public housing tenant dummy variable to be negative and significant.

Suppose the dummy variable $\mathrm{S}$ is equal to 0 if a tenant has moved to a new district in the previous five years, and $\mathrm{S}=1$ if the tenant stayed in the same district. Then the probability of $\mathrm{S}=1$ conditional on having moved in the past five years can be denoted by $\operatorname{Prob}(S=1 \mid M=1)$. This conditional probability can be estimated using the sub-sample of households that had moved in the previous five years. Hypothesis II predicts that the coefficient estimate for the public housing tenant dummy variable of this probit model is negative and significant.

Finally, let $\mathrm{W}=1$ if place of work and place of residence are in the same district (or in the same region), and $\mathrm{W}=0$ otherwise. Hypothesis III predicts that in a probit regression with $\mathrm{W}$ as the dependent variable, the coefficient estimate for the public housing tenant dummy variable is negative and significant.

\section{Empirical Results}

The data set we use in this study is the five percent random sub-sample of the 2001 Hong Kong Population Census. We include all heads of households aged 18 or above who were born in Hong Kong, Macau or Mainland China. By definition, a household refers to a housing 
domestic unit consisting of the members of a family who live together along with non-relatives. Thus, the location choice of a housing unit affects all members of the household concerned. In this paper, when analyzing the location choices made by a household, we primarily focus on the choices made by the household head. Extending the sample to cover all household members does not change any of our conclusions. ${ }^{4}$

Our primary objective is to compare the mobility and location decisions of public housing occupants with those of private housing occupants. We make a distinction between "Public Housing Tenants" and "Owner-Occupiers (Public)." The former refers to tenants in public housing rental estates, whereas the latter primarily refers to owners of subsidized HOS flats. Similarly, we make a distinction between "Private Housing Tenants" and "OwnerOccupiers (Private)," giving rise to a total of four different housing-tenure types. Since mobility and location decisions made (and constraints faced) by homeowners may be very different from those of rental tenants, we run regressions separately for these two distinct groups.

\section{(Insert Table 1 Here)}

Table 1 presents the summary statistics of all households by housing-tenure type. The data set consists of 96,690 observations. About 32 percent of these households were in public rental housing, and a further 15 percent were owners of government subsidized flats. The characteristics of the household heads were quite different across housing-tenure types. On average, household heads of public housing rental units were older, less educated, more likely to be female, and less likely to have young children than the other groups. They were also more likely to be unemployed or economically inactive. As expected, household income for public housing occupants was lower than that of their private housing counterparts. In our data, the average household income for public housing rental tenants was HK\$15,258 while that for private housing rental tenants was HK\$24,344. Similarly, owners of subsidized housing had an average income of HK\$24,965, compared to HK\$34,521 for owners of private housing.

\footnotetext{
${ }^{4}$ Since a housing unit is consumed by all members of a household simultaneously, including all household members in the analysis in effect gives more weight to larger households. As the conclusions do not change after expanding the data set, we choose not to present the empirical results in this paper.
} 
The population census file contains information about district of current residence as well as the district of residence five years ago. To present the geographical distribution of housing-tenure types in Table 1, we aggregate the 31 census districts of Hong Kong into three broad census regions as classified by the Census and Statistics Department: Urban Areas, New Towns, and Other Rural Areas. Urban Areas refer to District Council districts on Hong Kong Island and in Kowloon. New Towns include twelve new towns in the New Territories. Other Rural Areas cover the remaining areas in the New Territories. In Hong Kong, the public housing programme was commenced in 1954. At the beginning, public housing rental estates were built in urban areas, notably in Kwun Tong and Wong Tai Sin. As the population continued to expand, it reached a point when urban areas could not provide enough land to build adequate housing units to meet demand. To solve this problem, the Hong Kong government started building new towns to accommodate the ever increasing demand for housing. As discussed earlier, there are insufficient public rental housing units in the urban areas that can be allocated to all applicants; only public rental housing units in new towns will be allocated to new applicants. A typical new town is made up of several residential areas and each residential area mainly consists of both private and public housing estate clusters. In 2006, there are altogether twelve new towns and the latest one is located in North Lantau.

From Table 1, we can see that about 51 percent of the sample households were located in Urban Areas and another 44 percent were in New Towns. Among public housing rental tenants, the corresponding fractions were 48 percent and 51 percent. For owners of subsidized housing, approximately one-third of them lived in Urban Areas and two-thirds lived in New Towns. This pattern is reversed for private housing: there were far more private housing households in Urban Areas $(28,990)$ than in New Towns $(16,180)$. Households in Other Rural Areas only made up about five percent of all households. The fraction was even smaller among public housing tenants $(0.5$ percent), reflecting the fact that there were very few public housing rental estates constructed in rural places.

\section{A. Internal Mobility}


In order to test Hypothesis I, we estimate a probit model for the dummy variable $\mathrm{M}$, where $\mathrm{M}=$ 1 if a household had moved within the last five years. We estimate the model separately for tenants and owners, and the estimation results are shown in Tables 2A and 2B. Model 1 controls for gender, spouse-present, years of schooling, household income, household size, age group dummies, marital status dummies, activity status dummies, young children dummies, and district level fixed effects. Instead of reporting coefficient estimates, we report marginal effects of the probit regression.

Because of the substantial differences in observable characteristics between public and private housing tenants, we try to test the robustness of our results by introducing detailed control variables into our regression. Model 2 adds industry and occupational dummies, replaces the age category dummies by a fifth-order polynomial in age, and replaces the linear terms for income and household size by 100 dummies for income percentile and 10 dummies for household size. This model includes a total of over 400 independent variables in the regression and the full estimation results are not shown to avoid clutter. ${ }^{5}$ Model 3 is the same as Model 2 except that it further controls for spousal characteristics. It is estimated only on the sub-sample of tenants with spouse present. Finally Model 4 expands on Model 2 by introducing age times gender times control variable interactions (we replace the age polynomial by age group dummies in order to produce interaction terms). This last model is estimated using the full sample of tenants and it contains over 1100 control variables.

(Insert Tables 2A and 2B Here)

The effect of housing-tenure type on mobility is captured by the first dummy variable in the Tables. For example, the negative marginal effect estimate of -0.250 in the first column for "Public Housing Tenant" in Table 2A means that individuals in this group were 25 percent less likely to have moved in the past five years compared to rental tenants in private sector housing. The estimated effect is significant in the substantive sense as well as in the statistical sense. Notice that adding an extensive set of control variables and interaction terms does not materially change the size or the significance of the estimated effect of public housing tenancy

\footnotetext{
${ }^{5}$ Full regression results can be obtained from the authors.
} 
on internal mobility, as shown by the marginal effects of the "Public Housing Tenant" variable in Models 2, 3 and 4. These results are consistent with the prediction of Hypothesis I.

In the sample, 29.3 percent of public housing tenants had moved in the past five years, while 60.2 percent of the private tenants had done the same. If we use our probit model with the basic set of control variables (i.e., Model 1 of Table 2A) to impute the probability of moving for public housing tenants, the estimated probability turns out to be 29.3 percent, which is the same as the sample average. Assuming these public housing tenants all became private housing tenants, the model predicts that their probability of moving would change to 50.9 percent. In other words, the effect of public housing explains two-thirds of the observed difference in the probability of moving between public-housing tenants and private-housing tenants; the remaining difference can be attributable to differences in their other observable characteristics as specified in our probit model.

Table 2B shows that owner-occupiers of private housing are less likely to have moved in the previous five years compared to owner-occupiers of public housing. Buying a flat is a major investment decision with high fixed costs. Once a decision has been made, it tends to tie down owner-occupiers to their current location. It is therefore not surprising that the difference in estimated marginal effect between owner-occupiers of public versus private housing is smaller than that between tenants of public versus private housing. Nevertheless the estimated effect of -0.049 in Model 1 of Table 2B is highly significant statistically and is non-trivial in the substance sense, as the proportion of owner-occupiers who had moved in the past five years is only 36 percent. These results are consistent with our prediction that owners of public housing are more immobile than are owners of private housing. This conclusion remains the same whether we focus on the basic model with around 50 control variables or other models that include a few hundred observable control variables. Since adding spousal characteristics or interactions (i.e., Models 3 and 4) do not show substantial impact on the regression estimates, we will focus on the two basic Models 1 and 2 in the rest of this paper.

We can provide brief comments on the effects of the other control variables on the probability of moving. The gender of the household head is found to have small but negative effect on mobility for renters. However, this negative effect on mobility turns to be small 
positive effect for owner occupiers. Age, on the other hand, has strong effect on mobility. Generally, people in younger age groups have greater mobility than people in older age groups. For example, the estimated marginal effect for people aged 18-25 of the basic model in Table $2 \mathrm{~A}$ is 28.5 percentage points higher than that for people aged 61 or above (the omitted group). This positive effect on mobility increases to $45.9 \%$ for owner occupiers (Model 1 of Table 2B). With regard to marital status and employment status, we find that people who are married or divorced tend to be less mobile than people who are single, and that the unemployed are less mobile than employees.

We also find that education and household income are positively related to mobility, while household size is negatively related to it. However, the presence of young children increases the likelihood of moving. Based on the estimates in Model 1 of Table 2A, the probability of moving for households with children aged five or below is 19.7 percent higher than households without these young children, and the probability of moving for households with children aged six to ten is 13.7 percent higher than households without such children.

\section{B. Location Choice}

Conditional on moving, a household may choose to live in a new district or stay in the same district. Since Chinese culture encourages people to maintain close family links, it is a common phenomenon in Hong Kong that close relatives live in the same neighborhood. In many cases, different households of an extended family live in adjacent housing estates or even in the same block. In addition to the fact that people prefer to stay in familiar neighborhoods, the cultural norm suggests that, conditional on moving, households prefer to stay in the same

district of residence. Since private housing tenants have the highest flexibility in housing choice, their behaviour is a good indicator of their true preferences. Public housing tenants and owners of subsidized housing, on the other hand, have limited freedom in choosing a housing unit and their observed location choices may not necessarily reflect their true preferences. In this subsection, we only include in the sample those households that had moved in the previous five years. While Hypothesis I predicts that public housing occupants are less like to move, 
Hypothesis II predicts that, conditional on moving, public housing occupants are more likely to move outside their original neighborhood.

Boyle (1995) finds that in the United Kingdom long-distance migrants (those who moved over $50 \mathrm{~km}$ ) were less likely to move into council housing than other housing types. This finding is not inconsistent with our prediction because the geographical size of Hong Kong is small and moves in Hong Kong are rarely over $50 \mathrm{~km}$. Moreover, one reason for Boyle's result is that local authorities offer limited opportunities for public housing to migrate from outside the local area. In Hong Kong, by contrast, the allocation of public housing in all districts is under unified control by the Housing Authority.

In the estimation of this subsection, since we are restricting to households that had made a move in the previous five years, the sample size reduces to 37,013. Tables 3A and 3B show a probit model of location choice where the dependent variable is an indicator variable $\mathrm{S}$ for whether the household had moved within the neighborhood. More specifically, for the first two columns of the Table, we assume that the relevant "neighborhood" is a census district and we set $\mathrm{S}=1$ if the household had moved to a new residence in the same district, and $\mathrm{S}=0$ if the household had moved to a new residence in a different district. Recall that in our data file the territory of Hong Kong is divided into 31 census districts. The largest district according to this classification is Eastern district on Hong Kong Island, with a total of approximately 198,000 households. The median district is Wan Chai, and it has about 62,000 households. Census districts are the most detailed geographical subdivisions that are available in our data.

(Insert Tables 3A and 3B Here)

In the first column of Table 3A, we find that the marginal effect estimate for "Public Housing Tenant" is negative and statistically significant. The estimate implies that, conditional on moving, the probability of moving within the same census district is 5 percent lower among public housing tenants than among private housing tenants. This result is consistent with the prediction of Hypothesis II. In column two, we add detailed control variables (Model 2) and the estimated marginal effect for "Public Housing Tenant" becomes stronger (from -0.052 to $-0.077){ }^{6}$

\footnotetext{
${ }^{6} \mathrm{We}$ also run a probit regression with a full set of interaction variables and the results are essentially the same as Model 2. We choose not to report the detailed results in this paper but the full results can be obtained from the
} 
If we compare the behaviour of owner-occupiers (see column one of Table 3B), we find that the marginal effect estimate for "Owner-Occupier (Public)" stronger than that for "Public housing Tenant" as presented in Table 3A. The probability of within-district move is 17.6 percent lower for owners of public housing than for owners of private housing. This result is consistent with the prediction of Hypothesis IV.

In columns 3 and 4 of Table $3 \mathrm{~A}$ and $3 \mathrm{~B}$, we check the robustness of our results by using within-region move instead of within-district move as the dependent variable. Here, a region is defined in terms of the three categories of Urban, New Towns, and Rural that we explain above. Note that a census region as defined here encompasses a relatively large and not necessarily contiguous area. For example, a household that moved from one new town to another may encounter a completely different neighborhood. For this reason, we expect the results to be weaker than those in our preferred specifications of columns 1 and 2.

Comparing column 3 to column 1 of Table $3 \mathrm{~A}$, we find that the absolute size of the estimate marginal effect "Public Housing Tenant" is less than 0.01 and is no longer statistically significant at the one percent level. One reason for this result is that most of the public housing rental units that are available for allocation are located in New Towns. We discuss earlier that there are very few public housing rental estates in Other Rural Areas, while units in Urban Areas are mostly already occupied and unavailable for assignment. As a result, the relocation of public housing tenants is primarily within the New Towns region.

In columns 3 and 4 of Table 3B, the marginal effect estimate for "Owner-Occupier (Public)" remains negative and significant. For example, the estimates in column 4 suggest the owner-occupiers of public housing had a 14.2 percent lower probability of moving within the same census region compared to owner-occupiers of private housing. Although this effect is weaker than the corresponding estimate in column 2, the magnitude of the effect is still substantial. In short, the results presented in Tables 3A and 3B support Hypotheses II and IV.

One alternative interpretation for the finding that public housing occupants move further conditional on moving is a simple threshold model. Since the cost of moving is higher, they only move when it is really worthwhile to move, and it is really worthwhile to move if the

authors. 
optimal location is very far from the current location. According to this alternative interpretation, public housing tenants who moved should live closer to their place of work, assuming co-location of work and residence is one important determinant of optimal location. However we do not find evidence for this. Among public housing tenants who moved, 7.4 percent live in the same district as they work (the corresponding percentage for public housing tenants who did not move is 21.3 percent). Among private housing tenants who moved, 19.0 percent live in the same district as they work (the corresponding percentage for private housing tenants who did not move is 10.2 percent). These figures do not support the interpretation that conditional on moving, private tenants are moving to farther but "optimal" locations. We discuss the relationship between place of residence and place of work in greater detail in the subsection that follows.

\section{Place of Work}

Simpson (1987) develops a model in which residential location and workplace location are simultaneously determined (see also Siegel 1975; Kim et al., 2005). In this paper, we hypothesize that, due to lack of choice, public housing tenants are less likely to find a housing flat that is located close to their place of work. Moreover, the choice of residential and work location is inherently a dynamic decision (Vickerman 1984). The lack of mobility among public housing tenants hinders the attempt to adjust their residential location when circumstances change (such as changing to a new job), thus increasing the chance of a mismatch between place of residence and place of work. In this paper, we focus on the decision of the household head. Since unemployed or economically inactive persons do not report a place of work, the analysis in this subsection excludes such individuals. The resulting sample size with valid observations for the "Place of Work" variable is 53,334. We code the variable $\mathrm{W}$ equals 1 if the household head lives in the same district (or region) as he or she works, and $\mathrm{W}$ equals 0 otherwise. The resulting probit estimates are displayed in Tables 4A and 4B.

(Insert Tables 4A and 4B Here) 
The second column of Table 4A shows that public housing tenants are significantly less likely to work within the same census district of their residence compared to private housing tenants. The estimated marginal effect shows that the probability is 5 percent lower for public housing tenants than for the reference group of private housing tenants to reside in the same district as they work, holding other characteristics constant. From Table 4B, we find that the estimated marginal effect for "Owner-Occupier (Public)" is also negative (minus 3 percent) and significant. In other words, owners of public housing are less likely to work within the same district than are owners of private housing. Note that we already include census district dummies in our regressions. Thus our result is not driven by the fact that public housing estates tend to be located farther away from centers of economic activities. In other words, even if we compare between two households residing in the same census district, the one who lives in public housing (rented or owned) is more likely to hold cross-district employment than his or her counterpart in private housing.

In columns 3 and 4 of Tables $4 \mathrm{~A}$ and $4 \mathrm{~B}$, we define the dependent variable $\mathrm{W}$ in terms of whether the household head holds cross-region employment. The results are similar to those in the earlier specifications. Even after controlling for regional effects, occupants of public housing are less likely to hold a job within the same region of their residence than are their counterparts in private housing. These results are consistent with the prediction of Hypotheses III and V.

In a paper by Simpson (1980), he argues that a household residential location is also influenced by the work location of the secondary earners of the household. We therefore check the robustness of our results by changing the unit of observation to be the spouse of the household head. Since many household heads did not have spouses or had spouses who did not work, the sample size is further reduced to 27,490. Based on the specification of Model 2, we find that the marginal effect estimates for "Public Housing Tenant" and "Owner Occupier (Public)" in the equation for same-district employment are -0.038 and -0.057 respectively, and both are significant at the one percent level. If we replace district dummies by region dummies and focus on the likelihood of working in the same region, the estimated marginal effects become -0.056 and -0.066 for "Public Housing Tenant" and "Owner Occupier (Public)" 
respectively and both are statistically significant. Just like household heads, secondary earners in public housing, rented or owner occupied, have a lower probability of working in the same census district or region as they live when compared to secondary earners in private housing.

\section{Conclusions}

In Hong Kong, public housing confers a sizable subsidy to a large fraction of the population, and public housing units have to be rationed among competing households. Studies on public housing policy often focus on the fiscal burden imposed by such massive subsidies, but the allocative inefficiencies induced by rationing subsidized housing are less well documented in the literature. This study investigates the hidden costs of public housing from the perspective of the misallocation of housing units to tenants by examining how this misallocation affects these tenants' behaviour concerning internal mobility and travel-to-work.

This study makes use of the five percent random sub-sample of the 2001 Hong Kong Population census to test the following five hypotheses:

(i) public housing occupants are more immobile than private housing counterparts;

(ii) conditional on moving, public housing tenants are more likely than their private housing counterparts to have to move outside their original district or region of residence;

(iii) public housing tenants are less likely to work in the same district or region as their place of residence;

(iv) conditional on moving, public home owners are more likely than their private housing counterparts to have to move outside their original district or region of residence; and

(v) public home owners are less likely to work in the same district or region as their place of residence.

We estimate probit regressions on the census sample to test these hypotheses. All empirical results are statistically significant and consistent with our predictions. By identifying the distortions in location choices induced by public housing, this study serves to improve our estimate of the true costs of public housing policies in Hong Kong. Even though these costs are less tangible than the observable fiscal costs, they have a direct impact on tenants' everyday lives. Policy makers should explore the possibility of introducing private-market rent subsidies 
(see, for example, Gruis et al., 2005 and Johnson et al., 2002) to achieve the objective of providing affordable housing to the less well-to-do while avoiding many of the distortions due to government-provided housing.

Lastly, we would like to emphasize that our conclusions are based on correlations. While we have introduced extensive sets of control variables (sometimes totaling to around a thousand variables) in order to control for observable differences between public and private housing occupants, we still cannot exclude the possibility of differences in unobserved characteristics that may affect the outcome variables. Even though economic theory suggests a causal link between public housing occupancy and reduced residential mobility, the results presented here cannot provide definitive evidence for such a link. In the absence of experimental data or convincing instrumental variables, a causal interpretation of the results should be adopted with some caution.

\section{References}

Bansak, Cynthia; and Raphael, Steven (2008). “The State Children's Health Insurance Program and Job Mobility: Identifying Job Lock among Working Parents in Near-Poor Households." Industrial and Labor Relations Review 61 (July): 564-579.

Barzel, Yoram (1974). “A Theory of Rationing by Waiting.” Journal of Law and Economics 17 (April): 73-95.

Battu, Harminder; Ma, Ada; and Phimister, Euan (2008). "Housing Tenure, Job Mobility and Unemployment in the UK." Economic Journal 118 (March): 311-328.

Boyle, Paul (1995). "Public Housing as a Barrier to Long-Distance Migration.” International Journal of Population Geography 1 (December): 147-164.

Boyle, Paul; and Shen, Jianfa (1997). "Public Housing and Migration: A Multi-level Modelling Approach.” International Journal of Population Geography 3 (September): 227-242.

Census and Statistics Department (2002). 2001 Population Census: Main Report, Vol. 1. Hong Kong: Government Printer.

Cheung, Steven (1974). "A Theory of Price Control." Journal of Law and Economics 17 (April): 53-71. 
Deacon, Robert; and Sonstelie, John (1989). "The Welfare Costs of Rationing by Waiting." Economic Inquiry 27 (April): 179-196.

Deacon, Robert; and Sonstelie, John (1991). "Price Controls and Rent Dissipation with Endogenous Transaction Costs." American Economic Review 81 (December): 13611373.

Dohmen, Thomas J. (2005). "Housing, Mobility and Unemployment." Regional Science \& Urban Economics 35 (May): 305-325.

Elliott, James R. (1997). "Cycles within the System: Metropolitanisation and Internal Migration in the US, 1965-90." Urban Studies 34 (January): 21-41.

Feins, Judith D.; and Shroder, Mark D. (2005). “Moving to Opportunity: The Demonstration's Design and Its Effects on Mobility.” Urban Studies 42 (July): 1275-1299.

Gilleskie, Donna; and Lutz, Byron (2002). "The Impact of Employer-Provided Health Insurance on Dynamic Employment Transitions.” Journal of Human Resources 37 (Winter): 129-162.

Glaeser, Edward; and Luttmer, Erzo (2003). "The Misallocation of Housing under Rent Control." American Economic Review 93 (September): 1027-1046.

Greenwood, Michael J. (1985). "Human Migration: Theory, Models, and Empirical Studies." Journal of Regional Science 25 (November): 521-544.

Gruber, Jonathan; and Madrian, Brigitte (1994). "Health Insurance and Job Mobility: The Effects of Public Policy on Job-Lock." Industrial and Labor Relations Review 48 (October): 86-102.

Gruis, Vincent; Elsinga, Marja; Wolters, Arjen; and Priemus, Hugo (2005). "Tenant Empowerment through Innovative Tenures: An Analysis of Woonbron-Maasoevers' Client's Choice Programme." Housing Studies 20 (January): 127-147.

Helderman, Amanda C.; Mulder, Clara H.; and Van Ham, Maarten (2004). "The changing effect of home ownership on residential mobility in the Netherlands, 1980-98." Housing Studies 19 (July): 601-616.

Holtzer, Harry (1991). “The Spatial Mismatch Hypothesis: What Has the Evidence Shown?" Urban Studies 28 (February): 105-122. 
Hong Kong Housing Authority (2010a). "Population" in Housing in Figures 2009. http://www.housingauthority.gov.hk/en/aboutus/resources/figure/0,,00.html (visited on July 7, 2010).

Hong Kong Housing Authority (2010b). Public Rental Housing. http://www.housingauthority.gov.hk/en/residential/prh/0,,,00.html (visited on July 7, 2010).

Hong Kong Housing Authority (2010c). "Section A: Application for Public Housing, Transfer and Subsidized Home Ownership Schemes" in Public Housing Policies. http://www.housingauthority.gov.hk/en/aboutus/policy/publichousing/0,,3-0-30375,00.html (visited on July 7, 2010).

Huang, Youqin; and Deng, F. Frederic (2006). "Residential Mobility in Chinese Cities: A Longitudinal Analysis.” Housing Studies 21 (September): 625-652.

Hughes, Gordon A.; and McCormick, Barry (1987). "Housing Markets, Unemployment and Labour Market Flexibility in the UK." European Economic Review 31 (April): 61541.

Ioannides, Yannis M.; and Kan, Kamhon (1996). "Structural Estimation of Residential Mobility and Housing Tenure Choice.” Journal of Regional Science 36 (August): 335363.

Johnson, Michael P.; Ladd, Helen F.; and Ludwig, Jens (2002). "The Benefits and Costs of Residential Mobility Programmes for the Poor.” Housing Studies 17 (January): 125138.

Kain, John F. (1968). "Housing Segregation, Negro Employment, and Metropolitan Decentralization." Quarterly Journal of Economics 82 (May): 175-197.

Kan, Kamhon (2000). "Dynamic Modeling of Housing Tenure Choice.” Journal of Urban Economics 48 (July): 46-69.

Kan, Kamhon (2002). "Residential Mobility with Job Location Uncertainty." Journal of Urban Economics 52 (November): 501-523.

Kan, Kamhon (2003). "Residential Mobility and Job Changes under Uncertainty." Journal of Urban Economics 54 (November): 566-586. 
Kim, Jae Hong; Pagliara, Francesca; and Preston, John. "The Intention to Move and Residential Location Choice Behaviour.” Urban Studies 42 (August 2005): 16211636.

Koopmans, Tjalling C.; and Beckmann, Martin (1957). "Assignment Problems and the Location of Economic Activities." Econometrica 21 (January): 53-76.

Ludwig, Jens; Duncan, Greg J.; and Pinkston, Joshua C. (2005). "Housing Mobility Programs and Economic Self-sufficiency: Evidence from a Randomized Experiment." Journal of Public Economics 89 (January): 131-156.

Madrian, Brigitte (1994). "Employment-Based Health Insurance and Job Mobility: Is There Evidence of Job Lock?” Quarterly Journal of Economics 109 (February): 27-54.

Munch, Jakob Roland; Rosholm, Michael; and Svarer, Michael (2006). “Are Homeowners Really More Unemployed?” Economic Journal 116 (October): 991-1013.

Munch, Jakob Roland; Rosholm, Michael; and Svarer, Michael (2008). "Home ownership, job duration, and wages.” Journal of Urban Economics 63 (January): 130-145.

Painter, Gary (1997). "Does Variation in Public Housing Waiting Lists Induce Intra-urban Mobility?" Journal of Housing Economics 6 (September): 248-76.

Quigley, J.M. (2000). “A Decent Home: Housing Policy in Perspective.” In W.G. Gale and J.R. Pack (eds.), Brookings-Wharton Papers on Urban Affairs, 2000. Wahsington, D.C.: Brookings Instutition.

Rosenbaum, Emily; and Harris, Laura E. (2001). "Residential Mobility and Opportunities: Early Impacts of the Moving to Opportunity Demonstration Program in Chicago.” Housing Policy Debate 12 (2): 321-46.

Siegel, Jay (1975). "Intrametropolitan Migration: A Simultaneous Model of Employment and Residential Location of White and Black Households." Journal of Urban Economics 75 (January): 29-47.

Simpson, Wayne (1980). “A Simultaneous Model of Workplace and Residential Location Incorporating Job Search.” Journal of Urban Economics 80 (November): 330-339.

Simpson, Wayne (1987). "Workplace Location, Residential Location, and Urban Commuting." Urban Studies 24 (April): 119-128. 
Suen, Wing (1989). "Rationing and Rent Dissipation in the Presence of Heterogeneous Individuals.” Journal of Political Economy 97 (December): 1384-1394.

Vickerman, R. W. (1984). "Urban and Regional Change, Migration and Commuting - The Dynamics of Workplace, Residence and Transport Choice." Urban Studies 21 (February): 15-29.

Weitzman, Martin (1977). "Is the Price System or Rationing More Effective in Getting a Commodity to Those Who Need it Most?" Bell Journal of Economics 8 (Autumn): $517-524$.

Wilson, W.J. (1996). When Work Disappear: The World of the New Urban Poor. New York: Knopf.

Wong, Yue-Chim (1998). On Privatizing Public Housing. Hong Kong: City University of Hong Kong Press.

Wong, Yue-Chim; and Liu, Pak-Wai (1988). "The Distribution of Benefits among Public Housing Tenants in Hong Kong and Related Policy Issues." Journal of Urban Economics 23: 1-20. 
Table 1

Summary Characteristics by Housing-Tenure Type

\begin{tabular}{|c|c|c|c|c|c|}
\hline Variable & $\mathbf{A L L}$ & $\begin{array}{c}\text { Public Housing } \\
\text { Tenants }\end{array}$ & $\begin{array}{c}\text { Private Housing } \\
\text { Tenants }\end{array}$ & $\begin{array}{c}\text { Owner-Occupiers } \\
\text { (Public) }\end{array}$ & $\begin{array}{c}\text { Owner-Occupiers } \\
\text { (Private) }\end{array}$ \\
\hline$\overline{\text { Age (Years) }}$ & 50.60 & 56.11 & 46.80 & 47.45 & 48.70 \\
\hline Female & 28.46 & 34.11 & 26.00 & 23.71 & 26.42 \\
\hline Household Income (HK\$) & 24,867 & 15,258 & 24,344 & 24,965 & 34,521 \\
\hline Years of Schooling & 8.86 & 6.49 & 9.94 & 9.09 & 10.50 \\
\hline Household Size (Number) & 3.17 & 3.29 & 2.71 & 3.55 & 3.11 \\
\hline \multicolumn{6}{|l|}{ Marital Status } \\
\hline Married & 72.49 & 70.02 & 67.07 & 81.22 & 73.89 \\
\hline Divorced/Widowed & 15.85 & 23.83 & 13.19 & 10.13 & 12.08 \\
\hline \multicolumn{6}{|l|}{ Employment Status } \\
\hline Self-employed & 4.06 & 2.90 & 4.11 & 5.25 & 4.61 \\
\hline Employer & 7.05 & 1.91 & 9.12 & 5.77 & 11.53 \\
\hline Unemployed & 3.58 & 4.57 & 4.56 & 2.80 & 2.43 \\
\hline Economically Inactive & 33.09 & 49.32 & 26.01 & 22.32 & 25.92 \\
\hline \multicolumn{6}{|l|}{ Age Group } \\
\hline $18-25$ & 1.44 & 0.61 & 3.82 & 0.88 & 1.22 \\
\hline $26-40$ & 26.24 & 13.47 & 34.27 & 31.44 & 32.02 \\
\hline $41-60$ & 45.64 & 45.85 & 42.77 & 50.63 & 44.72 \\
\hline \multicolumn{6}{|l|}{ Children } \\
\hline Age $0-5$ & 10.97 & 6.87 & 12.19 & 13.74 & 13.07 \\
\hline Age $6-10$ & 14.21 & 13.60 & 12.47 & 17.36 & 14.32 \\
\hline \multicolumn{6}{|l|}{ Number of Households } \\
\hline Urban & 49,324 & 15,304 & 10,761 & 5,030 & 18,229 \\
\hline New Towns & 42,207 & 16,362 & 4,820 & 9,665 & 11,360 \\
\hline Rural & 5,159 & 162 & 2,055 & 48 & 2,894 \\
\hline Number of Observations & 96,690 & 31,828 & 17,636 & 14,743 & 32,483 \\
\hline
\end{tabular}


Table 2A

Probit Regression on Internal Mobility (Tenant)

(Moved in the Last Five Years)

\begin{tabular}{|c|c|c|c|c|}
\hline & Model 1 & Model 2 & Model 3 & Model 4 \\
\hline Public Housing Tenant & $\begin{array}{c}-0.25012 \\
(0.00634)^{* *}\end{array}$ & $\begin{array}{c}-0.23812 \\
(0.00664)^{* *}\end{array}$ & $\begin{array}{c}-0.24293 \\
(0.00908)^{* *}\end{array}$ & $\begin{array}{c}-0.2392 \\
(0.00670)^{* *}\end{array}$ \\
\hline Female & $\begin{array}{c}-0.02427 \\
(0.00601)^{* *}\end{array}$ & $\begin{array}{c}-0.02513 \\
(0.00635)^{* *}\end{array}$ & $\begin{array}{l}-0.01883 \\
(0.01224)\end{array}$ & $\begin{array}{c}-0.03157 \\
(0.00965)^{* *}\end{array}$ \\
\hline Spouse & $\begin{array}{c}0.03339 \\
(0.00853)^{* *}\end{array}$ & $\begin{array}{c}0.01824 \\
(0.01001)\end{array}$ & - & $\begin{array}{c}0.01626 \\
(0.01019)\end{array}$ \\
\hline Age & - & $\begin{array}{c}0.30706 \\
(0.06437)^{* *}\end{array}$ & $\begin{array}{l}-0.14496 \\
(0.16482)\end{array}$ & - \\
\hline $\mathrm{Age}^{2}$ & 一 & $\begin{array}{c}-0.01386 \\
(0.00270)^{* *}\end{array}$ & $\begin{array}{c}0.00262 \\
(0.00653)\end{array}$ & - \\
\hline $\mathrm{Age}^{3}, \mathrm{Age}^{4}, \mathrm{Age}^{5}$ & 一 & Yes & Yes & - \\
\hline Years of Schooling & $\begin{array}{c}0.00325 \\
(0.00070)^{* *}\end{array}$ & $\begin{array}{c}0.00187 \\
(0.00076)^{*}\end{array}$ & $\begin{array}{c}0.00048 \\
(0.00117)\end{array}$ & $\begin{array}{c}0.00288 \\
(0.00077)^{* *}\end{array}$ \\
\hline Married & $\begin{array}{c}-0.06968 \\
(0.01023)^{* *}\end{array}$ & $\begin{array}{c}0.0343 \\
(0.01102)^{* *}\end{array}$ & - & $\begin{array}{c}0.01585 \\
(0.01117)\end{array}$ \\
\hline Divorced/Widowed & $\begin{array}{l}-0.00517 \\
(0.00982)\end{array}$ & $\begin{array}{c}0.05478 \\
(0.01068)^{* *}\end{array}$ & - & $\begin{array}{c}0.03407 \\
(0.01079)^{* *}\end{array}$ \\
\hline Self-employed & $\begin{array}{c}-0.04578 \\
(0.01284)^{* *}\end{array}$ & $\begin{array}{c}-0.03193 \\
(0.01385)^{*}\end{array}$ & $\begin{array}{c}-0.03925 \\
(0.01668)^{*}\end{array}$ & $\begin{array}{c}-0.03569 \\
(0.01388)^{*}\end{array}$ \\
\hline Employer & $\begin{array}{l}-0.01268 \\
(0.01152)\end{array}$ & $\begin{array}{c}-0.0137 \\
(0.01354)\end{array}$ & $\begin{array}{c}-0.0074 \\
(0.01726)\end{array}$ & $\begin{array}{l}-0.01193 \\
(0.01365)\end{array}$ \\
\hline Unemployed & $\begin{array}{c}0.04068 \\
(0.01162)^{* *}\end{array}$ & $\begin{array}{c}0.01873 \\
(0.01259)\end{array}$ & $\begin{array}{c}0.01693 \\
(0.01726)\end{array}$ & \\
\hline Economically Inactive & $\begin{array}{l}-0.00694 \\
(0.00673)\end{array}$ & - & - & $\begin{array}{l}-0.01837 \\
(0.01260)\end{array}$ \\
\hline Child (Aged 0-5) & $\begin{array}{c}0.19681 \\
(0.00930)^{* *}\end{array}$ & $\begin{array}{c}0.16921 \\
(0.00988)^{* *}\end{array}$ & $\begin{array}{c}0.12291 \\
(0.01205)^{* *}\end{array}$ & $\begin{array}{c}0.18497 \\
(0.00985)^{* *}\end{array}$ \\
\hline Child (Aged 6-10) & $\begin{array}{c}0.13687 \\
(0.00775)^{* *}\end{array}$ & $\begin{array}{c}0.11406 \\
(0.00829)^{* *}\end{array}$ & $\begin{array}{c}0.07788 \\
(0.00982)^{* *}\end{array}$ & $\begin{array}{c}0.12324 \\
(0.00824)^{* *}\end{array}$ \\
\hline Child (Aged 11-18) & $\begin{array}{c}0.03747 \\
(0.00680)^{* *}\end{array}$ & $\begin{array}{c}0.0246 \\
(0.00732)^{* *}\end{array}$ & $\begin{array}{c}0.01454 \\
(0.00908)\end{array}$ & $\begin{array}{c}0.03212 \\
(0.00730)^{* *}\end{array}$ \\
\hline Aged $18-25$ & $\begin{array}{c}0.28544 \\
(0.01954)^{* *}\end{array}$ & - & - & $\begin{array}{c}0.30655 \\
(0.02435)^{* *}\end{array}$ \\
\hline Aged $26-40$ & $\begin{array}{c}0.1589 \\
(0.00946)^{* *}\end{array}$ & - & - & $\begin{array}{c}0.18691 \\
(0.01133)^{* *}\end{array}$ \\
\hline Aged $41-60$ & $\begin{array}{c}0.01307 \\
(0.00737)\end{array}$ & - & - & $\begin{array}{c}0.04168 \\
(0.00892)^{* *}\end{array}$ \\
\hline Household Size & $\begin{array}{c}-0.04448 \\
(0.00217)^{* *}\end{array}$ & - & - & - \\
\hline Household Income & $\begin{array}{c}1.26 \mathrm{E}-06 \\
(0.00000)^{* *}\end{array}$ & 一 & - & 一 \\
\hline District Dummies & Yes & Yes & Yes & Yes \\
\hline Spouse's Years of Schooling & - & - & $\begin{array}{c}0.00104 \\
(0.00113)\end{array}$ & - \\
\hline Spouse's Age - Age & - & - & Yes & - \\
\hline
\end{tabular}




$\begin{array}{lcccc}\text { Spouse's Employment Status } & - & - & \text { Yes } & - \\ 10 \text { Household Size Groups } & - & \text { Yes } & \text { Yes } & \text { Yes } \\ 100 \text { Income Percentile Groups } & - & \text { Yes } & \text { Yes } & \text { Yes } \\ \text { Industry Dummies } & - & \text { Yes } & \text { Yes } & \text { Yes } \\ \text { Occupation Dummies } & - & \text { Yes } & \text { Yes } & \text { Yes } \\ \text { Gender*Age_Group*Household_Size_Group } & - & - & - & \text { Yes } \\ \text { Gender*Age_Group*Income Percentile } & - & - & - & \text { Yes } \\ \text { Gender*Age_Group*Industry } & - & - & - & \text { Yes } \\ \text { Gender*Age_Group*Occupation } & - & - & - & \text { Yes } \\ \text { Spouse's Industry Dummies } & - & - & \text { Yes } & - \\ \text { Spouse's Occupation Dummies } & & & & \end{array}$


Table 2B

Probit Regression on Internal Mobility (Owner)

(Moved in the Last Five Years)

\begin{tabular}{|c|c|c|c|c|}
\hline & Model 1 & Model 2 & Model 3 & Model 4 \\
\hline \multirow[t]{2}{*}{ Owner Occupier (Public) } & -0.04921 & -0.04013 & -0.05295 & -0.03848 \\
\hline & $(0.00613)^{* *}$ & $(0.00632)^{* *}$ & $(0.00742)^{* *}$ & $(0.00632)^{* *}$ \\
\hline \multirow[t]{2}{*}{ Female } & 0.03868 & 0.03242 & 0.02982 & 0.02814 \\
\hline & $(0.00659)^{* *}$ & $(0.00705)^{* *}$ & $(0.01192)^{*}$ & $(0.01452)$ \\
\hline \multirow[t]{2}{*}{ Spouse } & 0.06394 & 0.0617 & - & 0.05758 \\
\hline & $(0.01208)^{* *}$ & $(0.01269)^{* *}$ & & $(0.01291)^{* *}$ \\
\hline \multirow[t]{2}{*}{ Age } & - & 0.40246 & -0.23617 & - \\
\hline & & $(0.08309)^{* *}$ & $(0.16506)$ & \\
\hline \multirow[t]{2}{*}{$\mathrm{Age}^{2}$} & - & -0.01872 & 0.006 & - \\
\hline & & $(0.00348)^{* *}$ & $(0.00667)$ & \\
\hline $\mathrm{Age}^{3}, \mathrm{Age}^{4}, \mathrm{Age}^{5}$ & 一 & Yes & Yes & - \\
\hline \multirow[t]{2}{*}{ Years of Schooling } & 0.00627 & 0.0011 & 0.00068 & 0.00285 \\
\hline & $(0.00076)^{* *}$ & $(0.00086)$ & $(0.00119)$ & $(0.00087)^{* *}$ \\
\hline \multirow[t]{2}{*}{ Married } & -0.02495 & 0.02789 & - & -0.01314 \\
\hline & $(0.01396)$ & $(0.01399)^{*}$ & & $(0.01441)$ \\
\hline \multirow{2}{*}{ Divorced/Widowed } & -0.0187 & 0.03545 & - & -0.01695 \\
\hline & $(0.01095)$ & $(0.01216)^{* *}$ & & $(0.01199)$ \\
\hline \multirow[t]{2}{*}{ Self-employed } & -0.00235 & 0.02262 & 0.02984 & 0.01163 \\
\hline & $(0.01102)$ & $(0.01203)$ & $(0.01378)^{*}$ & $(0.01192)$ \\
\hline \multirow[t]{2}{*}{ Employer } & 0.03454 & 0.04251 & 0.03971 & 0.03313 \\
\hline & $(0.00821)^{* *}$ & $(0.00984)^{* *}$ & $(0.01113)^{* *}$ & $(0.00979)^{* *}$ \\
\hline \multirow[t]{2}{*}{ Unemployed } & -0.05216 & 0.02525 & 0.00688 & 0.0329 \\
\hline & $(0.01440)^{* *}$ & $(0.01765)$ & $(0.02215)$ & $(0.01799)$ \\
\hline \multirow[t]{2}{*}{ Economically Inactive } & -0.07035 & - & - & - \\
\hline & $(0.00797)^{* *}$ & & & \\
\hline \multirow[t]{2}{*}{ Child (Aged 0-5) } & 0.07197 & 0.07454 & 0.05853 & 0.10915 \\
\hline & $(0.00814)^{* *}$ & $(0.00881)^{* *}$ & $(0.00995)^{* *}$ & $(0.00875)^{* *}$ \\
\hline \multirow[t]{2}{*}{ Child (Aged 6-10) } & -0.00928 & 0.00979 & 0.00854 & 0.01882 \\
\hline & $(0.0069)$ & $(0.00756)$ & $(0.00837)$ & $(0.00738)^{*}$ \\
\hline \multirow[t]{2}{*}{ Child (Aged 11-18) } & -0.02184 & -0.00074 & 0.00016 & 0.00622 \\
\hline & $(0.00656)^{* *}$ & $(0.00725)$ & $(0.00828)$ & $(0.00707)$ \\
\hline \multirow[t]{2}{*}{ Aged $18-25$} & 0.45878 & - & - & 0.47586 \\
\hline & $(0.01871)^{* *}$ & & & $(0.02193)^{* *}$ \\
\hline \multirow{2}{*}{ Aged $26-40$} & 0.32126 & - & - & 0.29733 \\
\hline & $(0.01019)^{* *}$ & & & $(0.01238)^{* *}$ \\
\hline \multirow[t]{2}{*}{ Aged $41-60$} & 0.09853 & 一 & - & 0.10967 \\
\hline & $(0.00910)^{* *}$ & & & $(0.01106)^{* *}$ \\
\hline \multirow[t]{2}{*}{ Household Size } & -0.03792 & - & - & - \\
\hline & $(0.00232)^{* *}$ & & & \\
\hline \multirow[t]{2}{*}{ Household Income } & $2.48 \mathrm{E}-06$ & - & - & - \\
\hline & $(0.00000)^{* *}$ & & & \\
\hline District Dummies & Yes & Yes & Yes & Yes \\
\hline Spouse's Years of Schooling & - & - & -0.00032 & - \\
\hline & & & $(0.00117)$ & \\
\hline Spouse's Age - Age ${ }^{5}$ & - & - & Yes & - \\
\hline
\end{tabular}




$\begin{array}{lcccc}\text { Spouse's Employment Status } & - & - & \text { Yes } & - \\ 10 \text { Household Size Groups } & - & \text { Yes } & \text { Yes } & \text { Yes } \\ 100 \text { Income Percentile Groups } & - & \text { Yes } & \text { Yes } & \text { Yes } \\ \text { Industry Dummies } & - & \text { Yes } & \text { Yes } & \text { Yes } \\ \text { Occupation Dummies } & - & \text { Yes } & \text { Yes } & \text { Yes } \\ \text { Gender*Age_Group*Household_Size_Group } & - & - & - & \text { Yes } \\ \text { Gender*Age_Group*Income Percentile } & - & - & - & \text { Yes } \\ \text { Gender*Age_Group*Industry } & - & - & - & \text { Yes } \\ \text { Gender*Age_Group*Occupation } & - & - & - & \text { Yes } \\ \text { Spouse's Industry Dummies } & - & - & \text { Yes } & - \\ \text { Spouse's Occupation Dummies } & - & - & \text { Yes } & -\end{array}$

Chi-squared

$10234.15 \quad 11751.81$

8407.59

11236.44

Notes: reporting marginal effects, standard errors are shown in parentheses $*$ - significant at 0.05 level $\quad * *$ - significant at 0.001 level 
Table 3A

Probit Regression on Locational Choice (Tenant)

\begin{tabular}{|c|c|c|c|c|}
\hline & \multicolumn{2}{|c|}{ Moved within the Same District } & \multicolumn{2}{|c|}{ Moved within the Same Region } \\
\hline & Model 1 & Model 2 & Model 1 & Model 3 \\
\hline \multirow[t]{2}{*}{ Public Housing Tenant } & -0.05177 & -0.07712 & 0.00943 & -0.0083 \\
\hline & $(0.00971)^{* *}$ & $(0.01020)^{* *}$ & $(0.00708)$ & $(0.00742)$ \\
\hline \multirow[t]{2}{*}{ Female } & 0.02882 & 0.02976 & 0.01777 & 0.02543 \\
\hline & $(0.00954)^{* *}$ & $(0.01014)^{* *}$ & $(0.00723)^{*}$ & $(0.00753)^{* *}$ \\
\hline \multirow[t]{2}{*}{ Spouse } & 0.01181 & -0.01526 & 0.03147 & 0.01193 \\
\hline & $(0.01351)$ & $(0.01570)$ & $(0.01057)^{* *}$ & $(0.01217)$ \\
\hline \multirow[t]{2}{*}{ Age } & - & -0.09219 & - & 0.08133 \\
\hline & & $(0.08958)$ & & $(0.06633)$ \\
\hline \multirow[t]{2}{*}{$\mathrm{Age}^{2}$} & - & 0.00469 & - & -0.00303 \\
\hline & & $(0.00385)$ & & $(0.00289)$ \\
\hline $\mathrm{Age}^{3}, \mathrm{Age}^{4}, \mathrm{Age}^{5}$ & - & - & - & - \\
\hline \multirow[t]{2}{*}{ Years of Schooling } & -0.01249 & -0.0107 & -0.00591 & -0.00369 \\
\hline & $(0.00115)^{* *}$ & $(0.00126)^{* *}$ & $(0.00091)^{* *}$ & $(0.00100)^{* *}$ \\
\hline \multirow[t]{2}{*}{ Married } & 0.00896 & 0.00247 & 0.00353 & 0.00253 \\
\hline & $(0.01487)$ & $(0.01633)$ & $(0.01137)$ & $(0.01247)$ \\
\hline \multirow[t]{2}{*}{ Divorced/Widowed } & 0.00447 & -0.01387 & 0.01902 & 0.0071 \\
\hline & $(0.01433)$ & $(0.01512)$ & $(0.01070)$ & $(0.01147)$ \\
\hline \multirow[t]{2}{*}{ Self-employed } & 0.00421 & -0.01207 & 0.01749 & 0.01944 \\
\hline & $(0.02095)$ & $(0.02212)$ & $(0.01555)$ & $(0.01617)$ \\
\hline \multirow[t]{2}{*}{ Employer } & 0.03424 & 0.03208 & 0.01469 & 0.02573 \\
\hline & $(0.01639)^{*}$ & $(0.01924)$ & $(0.01216)$ & $(0.01364)$ \\
\hline \multirow[t]{2}{*}{ Unemployed } & -0.00104 & -0.00428 & -0.02317 & - \\
\hline & $(0.01721)$ & $(0.01922)$ & $(0.01397)$ & \\
\hline \multirow[t]{2}{*}{ Economically Inactive } & 0.01382 & - & -0.00254 & 0.01504 \\
\hline & $(0.01093)$ & & $(0.00871)$ & $(0.01448)$ \\
\hline \multirow[t]{2}{*}{ Child (Aged 0-5) } & -0.04096 & -0.04716 & -0.01845 & -0.02862 \\
\hline & $(0.01211)^{* *}$ & $(0.01309)^{* *}$ & -0.00966 & $(0.01068) * *$ \\
\hline \multirow[t]{2}{*}{ Child (Aged 6-10) } & 0.02242 & 0.01399 & 0.01561 & 0.00955 \\
\hline & $(0.01107)^{*}$ & $(0.01202)$ & -0.00845 & $(0.00922)$ \\
\hline \multirow[t]{2}{*}{ Child (Aged 11-18) } & 0.0309 & 0.02034 & 0.02384 & 0.01506 \\
\hline & $(0.01092)^{* *}$ & $(0.01181)$ & $(0.00843)^{* *}$ & $(0.00916)$ \\
\hline \multirow[t]{2}{*}{ Aged $18-25$} & -0.16247 & - & -0.11112 & - \\
\hline & $(0.02276)^{* *}$ & & $(0.02288) * *$ & \\
\hline \multirow[t]{2}{*}{ Aged $26-40$} & -0.11408 & - & -0.0677 & - \\
\hline & $(0.01428)^{* *}$ & & $(0.01236)^{* *}$ & \\
\hline \multirow[t]{2}{*}{ Aged $41-60$} & -0.0456 & - & -0.03128 & - \\
\hline & $(0.01267)^{* *}$ & & $(0.01056)^{* *}$ & \\
\hline \multirow[t]{2}{*}{ Household Size } & 0.02377 & - & 0.00612 & - \\
\hline & $(0.00356)^{* *}$ & & $(0.00285)^{*}$ & \\
\hline Household Income & $-4.20 \mathrm{E}-07$ & - & $-1.48 \mathrm{E}-07$ & - \\
\hline & $(0.00000)^{*}$ & & $(0.00000)$ & \\
\hline 10 Household Size Groups & - & Yes & - & Yes \\
\hline 100 Income Percentile Groups & - & Yes & - & Yes \\
\hline District Dummies & Yes & Yes & - & - \\
\hline Region Dummies & - & - & Yes & Yes \\
\hline Industry Dummies & Yes & Yes & Yes & Yes \\
\hline Occupation Dummies & Yes & Yes & Yes & Yes \\
\hline Chi-squared & 1835.31 & 2232.52 & 1202.21 & 1494.44 \\
\hline
\end{tabular}

Notes: reporting marginal effects, standard errors are shown in parentheses * _ significant at 0.01 level $\quad * *$ _ significant at 0.001 level 
Table 3B

Probit Regression on Locational Choice (Owner)

\begin{tabular}{|c|c|c|c|c|}
\hline & \multicolumn{2}{|c|}{ Moved within the Same District } & \multicolumn{2}{|c|}{ Moved within the Same Region } \\
\hline & Model 1 & Model 2 & Model 1 & Model 3 \\
\hline \multirow[t]{2}{*}{ Owner Occupier (Public) } & -0.17604 & -0.18913 & -0.13521 & -0.14221 \\
\hline & $(0.00972)^{* *}$ & $(0.00992)^{* *}$ & $(0.00852) * *$ & $(0.00907)^{* *}$ \\
\hline \multirow[t]{2}{*}{ Female } & 0.02216 & 0.02613 & 0.01157 & 0.0113 \\
\hline & $(0.01072)^{*}$ & $(0.01159)^{*}$ & $(0.00905)$ & $(0.00972)$ \\
\hline \multirow[t]{2}{*}{ Spouse } & -0.01362 & -0.01999 & -0.00116 & -0.01529 \\
\hline & $(0.02279)$ & $(0.02387)$ & $(0.01954)$ & $(0.02015)$ \\
\hline \multirow[t]{2}{*}{ Age } & & -0.7341 & & -0.25615 \\
\hline & & $(0.14072)^{* *}$ & & $(0.12706)^{*}$ \\
\hline \multirow[t]{2}{*}{$\mathrm{Age}^{2}$} & & 0.03003 & & 0.00938 \\
\hline & & $(0.00605)^{* *}$ & & $(0.00545)$ \\
\hline $\mathrm{Age}^{3}, \mathrm{Age}^{4}, \mathrm{Age}^{5}$ & - & - & - & - \\
\hline \multirow[t]{2}{*}{ Years of Schooling } & -0.00865 & -0.00508 & -0.0054 & -0.00375 \\
\hline & $(0.00139)^{* *}$ & $(0.00163)^{* *}$ & $(0.00121)^{* *}$ & $(0.00141)^{* *}$ \\
\hline \multirow[t]{2}{*}{ Married } & -0.02869 & -0.02809 & -0.01069 & -0.00966 \\
\hline & $(0.02423)$ & $(0.02495)$ & $(0.02042)$ & $(0.02088)$ \\
\hline \multirow[t]{2}{*}{ Divorced/Widowed } & -0.07626 & -0.07054 & 0.01082 & 0.01122 \\
\hline & $(0.01858)^{* *}$ & $(0.01977)^{* *}$ & $(0.01702)$ & $(0.01783)$ \\
\hline \multirow[t]{2}{*}{ Self-employed } & 0.00493 & 0.00313 & -0.00823 & -0.0042 \\
\hline & $(0.01934)$ & $(0.02048)$ & $(0.01718)$ & $(0.01796)$ \\
\hline \multirow{2}{*}{ Employer } & 0.00519 & 0.02709 & -0.01168 & 0.00195 \\
\hline & $(0.01315)$ & $(0.01580)$ & $(0.01182)$ & $(0.01354)$ \\
\hline \multirow[t]{2}{*}{ Unemployed } & -0.01627 & & 0.01412 & 0.01716 \\
\hline & $(0.02867)$ & & $(0.02535)$ & $(0.02861)$ \\
\hline \multirow[t]{2}{*}{ Economically Inactive } & -0.01757 & -0.00209 & -0.02118 & \\
\hline & $(0.01627)$ & $(0.03294)$ & $(0.01496)$ & \\
\hline \multirow[t]{2}{*}{ Child (Aged 0-5) } & -0.00571 & -0.02085 & -0.00897 & -0.00803 \\
\hline & $(0.01203)$ & $(0.01331)$ & $(0.01046)$ & $(0.01174)$ \\
\hline \multirow[t]{2}{*}{ Child (Aged 6-10) } & 0.03891 & 0.03147 & 0.02173 & 0.02228 \\
\hline & $(0.01192)^{* *}$ & $(0.01295)^{*}$ & $(0.01008)^{*}$ & $(0.01095)^{*}$ \\
\hline \multirow{2}{*}{ Child (Aged 11-18) } & 0.12233 & 0.1099 & 0.0829 & 0.08126 \\
\hline & $(0.01252)^{* *}$ & $(0.01342)^{* *}$ & $(0.00970)^{* *}$ & $(0.01042)^{* *}$ \\
\hline \multirow[t]{2}{*}{ Aged $18-25$} & 0.10000 & & 0.08809 & \\
\hline & $(0.03467)^{* *}$ & & $(0.02345)^{* *}$ & \\
\hline \multirow[t]{2}{*}{ Aged $26-40$} & -0.04623 & & -0.00367 & \\
\hline & $(0.02033)^{*}$ & & $(0.01781)$ & \\
\hline \multirow[t]{2}{*}{ Aged $41-60$} & 0.00851 & & 0.01155 & \\
\hline & $(0.01939)$ & & $(0.01695)$ & \\
\hline \multirow[t]{2}{*}{ Household Size } & 0.02731 & & 0.02025 & \\
\hline & $(0.00422)^{* *}$ & & $(0.00371)^{* *}$ & \\
\hline \multirow[t]{2}{*}{ Household Income } & $-1.08 \mathrm{E}-06$ & & $-6.45 \mathrm{E}-07$ & \\
\hline & $(0.00000)^{* *}$ & & $(0.00000)^{* *}$ & \\
\hline 10 Household Size Groups & - & Yes & - & Yes \\
\hline 100 Income Percentile Groups & - & Yes & - & Yes \\
\hline District Dummies & Yes & Yes & - & - \\
\hline Region Dummies & - & - & Yes & Yes \\
\hline Industry Dummies & Yes & Yes & Yes & Yes \\
\hline Occupation Dummies & Yes & Yes & Yes & Yes \\
\hline Chi-squared & 2848.37 & 3095.49 & 1412.09 & 1653.04 \\
\hline
\end{tabular}

Notes: reporting marginal effects, standard errors are shown in parentheses

* _ significant at 0.01 level $\quad * *$ _ significant at 0.001 level 
Table 4A

Probit Regression on Place of Work (Tenant)

\begin{tabular}{|c|c|c|c|c|}
\hline & \multicolumn{2}{|c|}{ Worked within the Same District } & \multicolumn{2}{|c|}{ Worked within the Same Region } \\
\hline & Model 1 & Model 2 & Model 1 & Model 3 \\
\hline \multirow[t]{2}{*}{ Public Housing Tenant } & -0.03068 & -0.0519 & -0.02304 & -0.04555 \\
\hline & $(0.00838)^{* *}$ & $(0.00878)^{* *}$ & $(0.00795)^{* *}$ & $(0.00831)^{* *}$ \\
\hline \multirow[t]{2}{*}{ Female } & 0.09492 & 0.07591 & 0.0747 & 0.06337 \\
\hline & $(0.00898)^{* *}$ & $(0.00980)^{* *}$ & $(0.00828)^{* *}$ & $(0.00921)^{* *}$ \\
\hline \multirow[t]{2}{*}{ Spouse } & -0.02913 & -0.01816 & 0.00285 & 0.00295 \\
\hline & $(0.01290)^{*}$ & $(0.01407)$ & $(0.01344)$ & $(0.01484)$ \\
\hline \multirow[t]{2}{*}{ Age } & - & 0.03529 & - & 0.07525 \\
\hline & & $(0.09870)$ & & $(0.10670)$ \\
\hline \multirow[t]{2}{*}{$\mathrm{Age}^{2}$} & - & -0.00251 & - & -0.00349 \\
\hline & & $(0.00439)$ & & $(0.00476)$ \\
\hline $\mathrm{Age}^{3}, \mathrm{Age}^{4}, \mathrm{Age}^{5}$ & - & Yes & - & Yes \\
\hline \multirow[t]{2}{*}{ Years of Schooling } & -0.01222 & -0.00863 & -0.00459 & -0.00287 \\
\hline & $(0.00104)^{* *}$ & $(0.00120)^{* *}$ & $(0.00109)^{* *}$ & $(0.00128)^{*}$ \\
\hline \multirow[t]{2}{*}{ Married } & 0.05718 & 0.06291 & 0.0082 & 0.02173 \\
\hline & $(0.01344)^{* *}$ & $(0.01393)^{* *}$ & $(0.01523)$ & $(0.01632)$ \\
\hline \multirow[t]{2}{*}{ Divorced/Widowed } & 0.04353 & 0.0471 & 0.02322 & 0.02361 \\
\hline & $(0.01431)^{* *}$ & $(0.01538)^{* *}$ & $(0.01408)$ & $(0.01498)$ \\
\hline \multirow[t]{2}{*}{ Self-employed } & 0.12247 & 0.10937 & 0.05155 & 0.05318 \\
\hline & $(0.01487)^{* *}$ & $(0.01577)^{* *}$ & $(0.01310)^{* *}$ & $(0.01386)^{* *}$ \\
\hline \multirow[t]{2}{*}{ Employer } & 0.10377 & 0.13117 & 0.04398 & 0.07385 \\
\hline & $(0.01331)^{* *}$ & $(0.01591)^{* *}$ & $(0.01196)^{* *}$ & $(0.01308)^{* *}$ \\
\hline \multirow[t]{2}{*}{ Child (Aged 0-5) } & -0.037 & -0.02924 & -0.03005 & -0.03248 \\
\hline & $(0.00994)^{* *}$ & $(0.01073)^{* *}$ & $(0.01073)^{* *}$ & $(0.01156)^{* *}$ \\
\hline \multirow[t]{2}{*}{ Child (Aged 6-10) } & -0.02191 & -0.01191 & -0.00056 & -0.00104 \\
\hline & $(0.00851)^{*}$ & $(0.00936)$ & $(0.00883)$ & $(0.00969)$ \\
\hline \multirow[t]{2}{*}{ Child (Aged 11-18) } & -0.00575 & 0.0004 & -0.01253 & -0.01636 \\
\hline & $(0.00791)$ & $(0.00865)$ & $(0.00830)$ & $(0.00910)$ \\
\hline \multirow[t]{2}{*}{ Aged $18-25$} & -0.03603 & - & -0.05423 & - \\
\hline & $(0.02131)$ & & $(0.02583)^{*}$ & \\
\hline \multirow[t]{2}{*}{ Aged $26-40$} & -0.07039 & - & -0.05819 & 一 \\
\hline & $(0.01248)^{* *}$ & & $(0.01485)^{* *}$ & \\
\hline \multirow[t]{2}{*}{ Aged $41-60$} & -0.03402 & - & -0.03915 & 一 \\
\hline & $(0.01165)^{* *}$ & & $(0.01290)^{* *}$ & \\
\hline \multirow[t]{2}{*}{ Household Size } & 0.0104 & - & 0.00693 & - \\
\hline & $(0.00321)^{* *}$ & & $(0.00337)^{*}$ & \\
\hline \multirow[t]{2}{*}{ Household Income } & $-1.19 \mathrm{E}-06$ & - & $-4.99 \mathrm{E}-07$ & - \\
\hline & $(0.00000)^{* *}$ & & $(0.00000)^{* *}$ & \\
\hline 10 Household Size Groups & - & Yes & - & Yes \\
\hline 100 Income Percentile Groups & - & Yes & - & Yes \\
\hline District Dummies & Yes & Yes & - & - \\
\hline Region Dummies & - & - & Yes & Yes \\
\hline Industry Dummies & Yes & Yes & Yes & Yes \\
\hline Occupation Dummies & Yes & Yes & Yes & Yes \\
\hline Chi-squared & 1545.96 & 2657.75 & 2506.46 & 3299.26 \\
\hline
\end{tabular}

Notes: reporting marginal effects, standard errors are shown in parentheses * _ significant at 0.01 level $\quad * *$ _ significant at 0.001 level 
Table 4B

Probit Regression on Place of Work (Owner)

\begin{tabular}{|c|c|c|c|c|}
\hline & \multicolumn{2}{|c|}{ Worked within the Same District } & \multicolumn{2}{|c|}{ Worked within the Same Region } \\
\hline & Model 1 & Model 2 & Model 1 & Model 3 \\
\hline \multirow[t]{2}{*}{ Owner Occupier (Public) } & -0.03021 & -0.03329 & -0.03573 & -0.04247 \\
\hline & $(0.00615)^{* *}$ & $(0.00622)^{* *}$ & $(0.00672)^{* *}$ & $(0.00693)^{* *}$ \\
\hline \multirow[t]{2}{*}{ Female } & 0.07341 & 0.05775 & 0.06144 & 0.05207 \\
\hline & $(0.00743)^{* *}$ & $(0.00786)^{* *}$ & $(0.00774)^{* *}$ & $(0.00845)^{* *}$ \\
\hline \multirow[t]{2}{*}{ Spouse } & -0.02269 & -0.01411 & -0.02357 & -0.01745 \\
\hline & $(0.01414)$ & $(0.01441)$ & $(0.01692)$ & $(0.01769)$ \\
\hline \multirow[t]{2}{*}{ Age } & - & -0.01774 & - & 0.11978 \\
\hline & & $(0.10455)$ & & $(0.13653)$ \\
\hline \multirow[t]{2}{*}{$\mathrm{Age}^{2}$} & - & 0.00162 & - & -0.00598 \\
\hline & & $(0.00457)$ & & $(0.00609)$ \\
\hline $\mathrm{Age}^{3}, \mathrm{Age}^{4}, \mathrm{Age}^{5}$ & - & Yes & - & Yes \\
\hline \multirow[t]{2}{*}{ Years of Schooling } & -0.01287 & -0.00744 & -0.0087 & -0.00495 \\
\hline & $(0.00085)^{* *}$ & $(0.00101)^{* *}$ & $(0.00105)^{* *}$ & $(0.00128)^{* *}$ \\
\hline \multirow[t]{2}{*}{ Married } & 0.05309 & 0.04364 & 0.04812 & 0.0401 \\
\hline & $(0.01344)^{* *}$ & $(0.01377)^{* *}$ & $(0.01878)^{*}$ & $(0.01907)^{*}$ \\
\hline \multirow[t]{2}{*}{ Divorced/Widowed } & 0.05924 & 0.04544 & 0.06885 & 0.05981 \\
\hline & $(0.01368)^{* *}$ & $(0.01400)^{* *}$ & $(0.01407)^{* *}$ & $(0.01495)^{* *}$ \\
\hline \multirow[t]{2}{*}{ Self-employed } & 0.162 & 0.13778 & 0.09429 & 0.08631 \\
\hline & $(0.01220)^{* *}$ & $(0.01277)^{* *}$ & $(0.01138)^{* *}$ & $(0.01223)^{* *}$ \\
\hline \multirow[t]{2}{*}{ Employer } & 0.11067 & 0.11339 & 0.05579 & 0.06766 \\
\hline & $(0.00834)^{* *}$ & $(0.00997)^{* *}$ & $(0.00857)^{* *}$ & $(0.00994)^{* *}$ \\
\hline \multirow[t]{2}{*}{ Child (Aged 0-5) } & -0.02205 & -0.02654 & -0.01667 & -0.02673 \\
\hline & $(0.00738)^{* *}$ & $(0.00782)^{* *}$ & $(0.00899)$ & $(0.00998)^{* *}$ \\
\hline \multirow[t]{2}{*}{ Child (Aged 6-10) } & -0.0029 & -0.00508 & -0.00086 & -0.00692 \\
\hline & $(0.00661)$ & $(0.00710)$ & $(0.00797)$ & $(0.00878)$ \\
\hline \multirow[t]{2}{*}{ Child (Aged 11-18) } & -0.00175 & -0.0055 & 0.01318 & 0.0023 \\
\hline & $(0.00633)$ & $(0.00685)$ & $(0.00777)$ & $(0.00860)$ \\
\hline \multirow[t]{2}{*}{ Aged $18-25$} & -0.03419 & - & -0.00304 & - \\
\hline & $(0.02109)$ & & $(0.02794)$ & \\
\hline \multirow[t]{2}{*}{ Aged $26-40$} & -0.06209 & - & -0.03435 & - \\
\hline & $(0.01146)^{* *}$ & & $(0.01599)^{*}$ & \\
\hline \multirow[t]{2}{*}{ Aged $41-60$} & -0.04809 & - & -0.0239 & - \\
\hline & $(0.01113)^{* *}$ & & $(0.01526)$ & \\
\hline \multirow[t]{2}{*}{ Household Size } & 0.01893 & - & 0.01247 & - \\
\hline & $(0.00238)^{* *}$ & & $(0.00294)^{* *}$ & \\
\hline \multirow[t]{2}{*}{ Household Income } & $-1.15 \mathrm{E}-06$ & - & $-5.34 \mathrm{E}-07$ & - \\
\hline & $(0.00000)^{* *}$ & & $(0.00000)^{* *}$ & \\
\hline 10 Household Size Groups & - & Yes & - & Yes \\
\hline 100 Income Percentile Groups & - & Yes & - & Yes \\
\hline District Dummies & Yes & Yes & - & - \\
\hline Region Dummies & - & - & Yes & Yes \\
\hline Industry Dummies & Yes & Yes & Yes & Yes \\
\hline Occupation Dummies & Yes & Yes & Yes & Yes \\
\hline Chi-squared & 3135.42 & 4173.88 & 6100.46 & 6789.53 \\
\hline
\end{tabular}

Notes: reporting marginal effects, standard errors are shown in parentheses

* _ significant at 0.01 level $\quad * *$ _ significant at 0.001 level 